\title{
Chapter 23 \\ Diaspora Policies, Consular Services and Social Protection for Portuguese Citizens Abroad
}

\author{
José Carlos Marques and Pedro Góis
}

\subsection{Introduction}

Portugal is a traditional country of emigration with a multigenerational diaspora spread across a large number of countries. ${ }^{1}$ In the last 50 years, especially after the 1974 revolution, it developed a welfare state that responds to the needs of its residents (including immigrants). Traditionally, this welfare state has been described as fragile in comparison with other welfare regimes in Europe. Nevertheless, it was built as a universal welfare system based on jus solis and deterritorialized jus sanguinis regime. The study of the extension of social protection to Portuguese citizens living abroad had not yet received sufficient attention, albeit recurrent news on measures and strategies that the state put in practice to assist Portuguese emigrants in need.

The protection of its citizens is one of the functions of the nation-state inscribed in most national Constitutions. The extension of this 'right to protection' beyond the frontiers of the country has been a constant concern of the Portuguese legislator, at least since the massive emigration flow of Portuguese citizens to Brazil at the end of the nineteenth century and the beginning of the twentieth century. During this period, the state was mainly worried about the regulatory functions necessary to guarantee safe (or at least human) travelling and working conditions, and with the expatriation of its citizens in case of need.

\footnotetext{
${ }^{1}$ Recent data from the Ministry of Foreign Affairs show the presence of Portuguese migrants in 178 of the 193 countries belonging to the United Nations.
}

J. C. Marques ( $\square)$

Polytechnic of Leiria, Leiria, Portugal

e-mail: jose.marques@ipleiria.pt

P. Góis

University of Coimbra, Coimbra, Portugal

(C) The Author(s) 2020

J.-M. Lafleur, D. Vintila (eds.), Migration and Social Protection in Europe and Beyond (Volume 2), IMISCOE Research Series, https://doi.org/10.1007/978-3-030-51245-3_23 
With the institutionalization of the welfare state, late in the twentieth century, ${ }^{2}$ the protection of citizens expanded to include new spaces of state intervention with the objective to support the risks of unemployment, work injury, sickness, maternity, old age, disability, survivors, and family allowances and access to education or housing of its members (mainly its citizens). The classical concept of the welfare state rested on the principle to ensure each individual protection due to his/her membership in the national society. Since members of a society make their livelihood in a specific nation-state, belonging to a national society means belonging to a particular national territory. The conceivable extension of this individual protection to citizens living in another country allow us to analyse Portugal's engagement policies and measures that simultaneously contribute to nurture the sense of communities abroad and emigrants' attachment with the country of origin (Gamlen 2008). As with other policies aiming emigrant engagement (see Marques and Góis 2014), the analysis of the social protection of Portuguese citizens abroad reveals that Portugal's initiatives to maintain links with citizens abroad are recurrently fragmented and tenuous. Taken together, they form a constellation of institutional and legislative measures and programs that evolve through time accompanying the establishment of Portuguese communities abroad. Cultural engagement policies and the extension of political rights to citizens abroad have been the most disputed policies given their greater visibility and likelihood to render political gains (either for governing parties, or for the opposition). Albeit protecting its citizens abroad has been a longstanding concern in the political debates and the legislation on emigration, the spread of social protection policies to emigrants is a more recent fact and therefore lacks a systematic analysis. To contribute to this study, this chapter focuses on diaspora and consular policies developed by Portugal in response to the social protection needs of its citizens abroad. The first part of the chapter presents the general institutional framework by which Portugal assists nationals abroad and the main engagement policies with the diaspora. The second part presents the main features and explains the development of the country's diaspora policies across five specific welfare areas: unemployment, health care, pensions, family benefits, guaranteed minimum resources.

\footnotetext{
${ }^{2}$ Miriam Halpern Pereira (2005) defends that the Portuguese welfare state started as early as the first quarter of the twentieth century.
} 


\subsection{Diaspora Policy Infrastructure and Key Policies}

\subsubsection{The Portuguese Diaspora and Its Relations with the Homeland}

Portugal had traditionally been a country of emigration taking part, like other European countries, in the two great migratory waves of the nineteenth and twentieth century. The first one (from the nineteenth century to the 1960s) went mainly to Brazil and the United States that accounted, respectively, for $68 \%$ and $18 \%$ of those that left Portugal. The second migratory wave lasted from the 1960s until the early 1970s and was directed towards industrialized countries of Northern and Central Europe, mainly France and Germany which respectively accounted for 63,9\% and 13,3\% of Portuguese emigrants between 1960 and 1974 (Baganha and Marques 2001). The economic crisis of $1973 / 74$ put an end to this intra-European migration movement. After this date, Portuguese emigration was marked by periods of contraction (1970s to mid-1980s), expansion (mid-1980s onwards), and then an intensification of the expansion (from the end of 2000 onwards) (Marques and Góis 2013a). In recent years, Portuguese emigration has both risen substantially and diversified its range of destinations. Currently, there are movements towards traditional destination countries alongside migrations to new territories, the outflow thus becoming geographically more diversified and dispersed.

Because of this continuous outflow, estimates show that the number of Portuguese-born and their descendants living in another country is currently between 2 and 4.8 million. ${ }^{3}$ Data on the geographical distribution of this population are not available in the official statistics mainly due to lack of information on the country of birth of the ancestors of emigrants' descendants born in the country of residence. Older migratory flows are normally less visible in current statistics, although descendants of Portuguese nationals born abroad with, at least, one Portuguese ascendant in the second degree (grandparent) of the direct line who has not lost this citizenship are entitled to Portuguese citizenship. Existent data are generally based either on citizenship, or on peoples' place of birth. Based on this last criterion, the main countries of residents are France (621,777 Portuguese-born in 2015), Switzerland (220,904 in 2017), Brazil (169,069 in 2017), Canada (161,055 in 2017), United States of America (148,208 in 2016), United Kingdom (139,000 in 2017), and Germany (123,155 in 2017).

Throughout its history, Portugal has sought to maintain contact with its citizens abroad. Interactions with emigrants have been mainly limited to the cultural and political dimensions and trace a preponderantly unidirectional relationship (from

\footnotetext{
${ }^{3}$ Data on emigrants and their descendants inscribed at a Portuguese Consular post point to $5,740,787$ Portuguese abroad. These data should be interpreted cautiously since they include citizens that could already have returned to Portugal and exclude Portuguese descendants that are automatically entitled to Portuguese citizenship if they fill the claim (Portal das Comunidades Portuguesas 2019).
} 
the state to citizens abroad). Yet, the development of Portugal's engagement policies needs also to consider the reception context that influences the development of specific opportunities to support origin engagement (for example, the development of Portuguese language and culture courses is determined by the educational policies of the destination state). We undertake this task partially by looking at specific policies developed in the major countries of destination of Portuguese emigrants.

\subsubsection{Diaspora Infrastructure}

Despite this long and lasting emigration flow and the presence of sizeable communities of Portuguese citizens and their descendants in multiple countries, there is no ministry in Portugal that acknowledges in its official name that one of its core missions is to deal with diaspora and/or emigration questions (there is only a general Ministry of Foreign Affairs ${ }^{4}$ that includes a Secretary of State for communities abroad). The General Directorate of Consular Affairs and Portuguese Communities (DGACCP) is the responsible entity for questions regarding Portuguese citizens abroad. Its functions include the coordination and implementation of the policy to support emigration and the Portuguese communities abroad. This General Directorate is part of the Ministry of Foreign Affairs.

Consular services focus mainly on the defence of the rights and interests of the Portuguese state and of its citizens. Its action is comprehensive in terms of matters (electoral census, identification cards and passports, travel documents, certificates and solicitations, legalization of documents, issues relating to civil and criminal registration, etc.). In terms of support, they identify three general areas: cultural and associative movement; and social and legal areas (Portal das Comunidades Serviços Consulares, 2016).

At regional level, the autonomous Region of Azores have a Regional Directorate of the Communities that has, among its functions, dialogue promotion between immigrant and emigrant communities and their representatives and encourages civic and political participation in the societies in which they are inserted. ${ }^{5}$

\section{The Portuguese Consular Network}

The Portuguese consular network has representation on the five continents. It includes different types of consular structures:

- General consulate, with a fixed address;

- Consulate, with a fixed address;

- Vice-Consulate, with a fixed address and punctual permanencies in some cities (on specific dates);

- Consular section, with a fixed address and specific working hours;

\footnotetext{
${ }^{4}$ Between 2002 and 2005 a Ministry of Foreign Affairs and Portuguese Communities existed.

${ }^{5}$ Source: Governo dos Açores (2018).
} 
- Honorary consulate, which is equal to the consulate in the functions of defending the rights and interests of the Portuguese state and its nationals, but sees its competences limited to the practice of consular acts such as electoral census, civil registration and notary acts and issuing travel documents (and these functioned only in particular conditions and duly substantiated);

- Consular office, with a fixed address and specific working hours.

To ensure consular support to citizens within the area of jurisdiction of the consular post, the legislation allows the functioning of mobile consulates that offer consular services outside the city where the consulate is based. ${ }^{6}$ These mobile consulates assure the realisation of all consular services such as issuing of Citizen Card and passport, electoral census and civil registry, among others. This is possible thanks to a technologically advanced computer that allows an accredited employee to capture citizens' image, signature and fingerprint on time, as if it were on the premises of the consulate. In 2017, 618 consular permanencies were carried out in which 34,814 citizens were attended. ${ }^{7}$

In total, in 2018, the Portuguese consular network was composed of 345 posts. ${ }^{8}$ Its presence in different continents is variable and the type of consular structure is geographically diverse (Fig. 23.1). Most of the consular structures are in the Americas and in Europe that together have around $60 \%$ of the total consular institutions that compose the Portuguese consular network. The largest number of consular institutions are in countries that have been traditional countries of destination

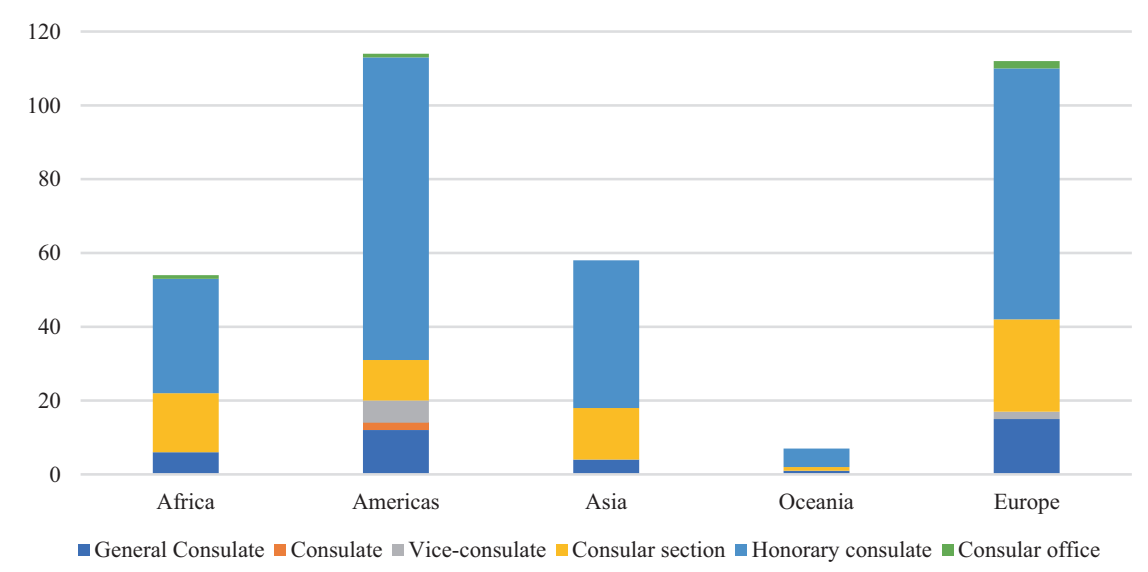

Fig. 23.1 Portuguese Consular network by continent and type, 2018. (Source: Authors elaboration based on data from the Portuguese Communities Portal Portal das Comunidades Portuguesas 2018c)

\footnotetext{
${ }^{6}$ For a list of mobile consulates, see Portal das Comunidades (2018b).

${ }^{7}$ Source: Portal das Comunidades (2019).

${ }^{8}$ Includes 38 general consulates, two consulates, eight vice-consulates, 68 consular sections, four consular offices, and 226 honorary consulates.
} 
of Portuguese emigrants, like Brazil (36 consular institutions), the USA (19), and France (17).

Regarding other representative or consultative institutions, it is worth mentioning that in 1980, the Government created the Council of Portuguese Communities (Conselho das Comunidades Portuguesas) ${ }^{9}$ as a form to maintain an institutional dialogue with citizens abroad (Aguiar 2009). The role of the Council is mainly a consultative one, advising the Government in matters related to emigration and Portuguese citizens abroad (Marques and Góis 2013b). Council's activities were interrupted between 1988 and 1996. Since this date, the Council has broadened its scope of action being responsible for issuing opinions on drafts of law and other projects of legislative and administrative acts, as well as on international agreements or regulations relating to the Portuguese citizens abroad. Beside this consultative function, the Council also provides information and issues opinions on all matters relevant for Portuguese residents abroad and direct them to the member of the Government responsible for the areas of emigration and of the Portuguese communities and formulate proposals and recommendations on the policy for the Portuguese communities.

The Council is composed of a maximum of 80 members elected for a four-year mandate by Portuguese residing abroad which are electors of the Portuguese Legislative Assembly. Members are elected in electoral districts (círculos eleitorais) in countries with a significant population of Portuguese citizens. ${ }^{10}$

The Council's works is organized in plenary session, a permanent council, thematic committees, regional councils, sections and subsections. It meets in plenary once per mandate and more frequently only if justified by particular reasons (Portal das Comunidades Portuguesas 2018a). Its main function is of an advisory nature. It has direct involvement in activities related to social protection. One of its Thematic Committees is on social and economic questions and migrations flows. The mission of this Committee is to draw up reports and studies on specific matters of its intervention areas (Article 3 of the rules of procedure of the Committee) (Portal das Comunidades Portuguesas 2018e). These reports and studies are not however publicly available and thus it is not possible to analyse the positions of the Council in issues related the access to social protection of Portuguese citizens abroad.

Lastly, parties that are currently present in the Parliament do not have a special department for citizens abroad in their organizational infrastructure. However, in the elections for the Legislative Assembly, the two main political parties (Socialist and Social Democrats) regularly elect the four deputies that are elected in the two extra-territorial electoral districts (one district for Portuguese citizens residing in Europe and the other one for Portuguese residing outside of Europe).

\footnotetext{
${ }^{9}$ Decree-Law n ${ }^{\circ} 373 / 80$ of September 12.

${ }^{10}$ South Africa, Germany, Andorra, Angola, Argentina, Australia, Belgium, Brazil, Cape Verde, Canada, China, Spain, United States, France, United Kingdom, Guinea Bissau, India, Luxembourg, Mozambique, Namibia, The Netherlands, Curaçao, São Tomé and Principe, Sweden, Switzerland, East Timor, Uruguay, Venezuela.
} 


\subsubsection{Key Engagement Policies}

The Strategic Plan for Migrations (PEM) for the period 2015-2020 (Governo de Portugal 2015) includes a set of measures directed towards immigrants in Portugal and Portuguese emigrants. The policies directed towards citizens abroad are aiming primarily at encouraging, monitoring and supporting their return to Portugal. The Plan also foresees a set of measures intended to strengthen the links between citizens abroad and their homeland. The following measures coordinated by the Ministry of Foreign Affairs are proposed in the PEM:

- Implementation of measures to support citizens abroad (through the expansion of the instruments of the consular network, like consular permanencies);

- Stimulating and consolidating the ties with Portugal, promoting and disseminating the Portuguese language and culture as well as associations for the benefit of the Portuguese communities abroad (trough the support to initiatives and projects of the associative movement);

- Encouraging the integration and civic and political participation of the emigrant in societies and host communities;

- Stimulating economic and entrepreneurial relations between citizens abroad and Portugal and attracting emigrant entrepreneurs to Portugal (Governo de Portugal 2015).

The analysis of the historical development of these measures shows that they have followed, albeit not always immediately, the evolution of the emigration flows, the constitution of sizeable and stable communities of Portuguese citizens abroad, and the economic and political interests of Portugal. This is clear in the evolution of the consular structure or in the measures intended to support the teaching of Portuguese language and culture to emigrants' descendants.

One central policy of engagement of Portugal with citizens concerns voting rights through which the state has sought to incorporate politically its citizens living abroad. In the case of the elections for the Legislative Assembly, the right of participation of Portuguese emigrants is guaranteed, since 1976. Irrespective of the years spent abroad, Portuguese enrolled in the electoral census abroad can vote by correspondence or in person at a consulate, embassy, delegations of Portuguese ministries or institutions previously defined by the Minister of the Interior (the process is the same for the other elections). Emigrant voters are grouped in two electoral districts: the electoral district 'Europe' and the electoral district 'Rest of the World' (Santana-Pereira and Horta 2017). Both circles elect two members (out of a total of 230) and it is therefore frequent, especially during electoral campaigns, that the candidates for the emigration circles intensify their contacts with the emigrants (Marques and Góis 2013b; Costa 2000). It is worth mentioning that, once elected, these four members of the parliament are not expected to defend the interest of electoral district in which they were elected, but the national interest (like all other members of the parliament) (Rodrigues et al. 2013). 
Since the fourth constitutional revision in 1997, emigrants have been allowed to vote in the presidential elections. Although article 121 of the Constitution requires an effective connection of the emigrant to the national community as a condition to vote from abroad, the legal framework created for the election of the President of the Republic did not take this condition into consideration (Marques and Góis 2013b; Costa 2000), allowing thus Portuguese citizens abroad to vote in presidential elections.

The involvement of migrants in national political issues is also possible via participation in certain referenda (which affect them directly ${ }^{11}$ ), and European Parliament elections. ${ }^{12}$

Data on the political participation of the Portuguese abroad show that the extension of electoral rights has not been accompanied by an expansion of the effective involvement of Portuguese emigrants in the different electoral processes. ${ }^{13}$ More than expressing a lack of interest or detachment from national political issues of Portuguese citizens abroad, the low levels of registration in the electoral census and even lower turnout levels reflect the inadequacy of the existent mechanisms to promote emigrants' political participation (Marques and Góis 2014, 2013b).

The creation of legal conditions for emigrants' political participation has been accompanied by a resistance to adopt methods that could allow voting from abroad. The imposition of a vote in person for certain elections (presidential and European elections) and the mismatch between the location of voting places (usually in embassies or consulates) and the regions where migrants live, constitute the main factors that constrain emigrants' turnout (Marques and Góis 2014).

The automatic census of emigrants abroad (that started in 2018) will allow an increase in the number of citizens enrolled in the electoral census (to more than one million Portuguese citizens abroad, according to governmental sources). Since this measure is not followed by a change in the voting methods, it is expected that it will lead to a rise in the abstention rate. ${ }^{14}$

\section{Education and Culture}

To produce and intensify the relation between migrants and the country of origin, the Portuguese state developed a program of teaching of Portuguese language and culture directed to the children of migrants (known nowadays as 'Portuguese Inheritance Language)'. This program was created in 1973 and is executed in institutional contexts that are strongly influenced by the policies of the host countries concerning the integration of the teaching of immigrants' mother tongue in their school system (Aguiar 2009). State support for these courses was, until 1 February

\footnotetext{
${ }^{11}$ Art. ${ }^{\circ} 37$, n. ${ }^{\circ} 2$ of Organic Law n. ${ }^{\circ}$ 4/2005, 8 of September.

${ }^{12}$ Law n ${ }^{\circ} 14 / 87,29$ April.

${ }^{13}$ In the 2015 election for the Legislative Assembly, 242,849 Portuguese emigrants were enrolled in the electoral census and only 11,8\% cast their vote (Comissão Nacional de Eleições 2015).

${ }^{14}$ For the 2019 election for the Legislative Assembly, 1,466,754 Portuguese citizens were enrolled to vote and only $10,8 \%$ cast their vote (Secretaria Geral do Ministério da Administração Interna 2020)
} 
2010, managed by the Ministry of Education, and from this date onward, it is coordinated by the Camões Institute. Last available data refer to 2017, showing that Portuguese language and culture courses were taught to 68,758 students in 17 countries,${ }^{15}$ at the preschool, basic and secondary education level (Gabinete do Secretário de Estado das Comunidades Portuguesas 2018). These courses did not lead to any degree, they only certify the knowledge of Portuguese language if the student passes the Portuguese language exam.

Camões Institute is a public institute with administrative and financial autonomy and its own assets. Its missions are, among others, to: (a) propose and implement the Portuguese cooperation policy (mainly with Portuguese-speaking countries); (b) propose and implement education and dissemination policies relating to the Portuguese language and culture internationally; (c) ensure the management of the Portuguese educational network abroad in primary, secondary and higher education; (d) promote the internationalisation of Portuguese culture (Instituto Camões 2018).

Camões Institute is in charge of implementing Ministry of Foreign Affairs' missions in the area of culture. In this area, it ensures the promotion and diffusion of Portuguese culture abroad by designing, producing, proposing and promoting activities and projects to increase international awareness of all the different types of artistic expression. These activities are executed directly by the Institute and their regional sections abroad, frequently in close association with Portuguese consulates or embassies. The total budget of the Camões Institute was, in 2018, 68 million euros, from which 26,6 million were allocated to the teaching of Portuguese language and culture program, 27,9 million to international cooperation, and 6,2 million to cultural initiatives developed under the programme 'Portuguese presence abroad'.

Another measure at the educational level directed towards citizens abroad is the existence of a specific number of vacancies to access higher education for Portuguese migrant candidates and family members who are residing with them. Every year, $7 \%$ of the vacancies set for the first stage of the national access competition is reserved for candidates that are Portuguese citizens abroad and their family members who reside with them. ${ }^{16}$

Another area of engagement is the support of Portuguese associations abroad. Managed by the Ministry of Foreign Affairs, this support is focused on the actions developed by the associative movement of the Portuguese communities. Funding is provided for actions and projects that contribute to the promotion of Portuguese

\footnotetext{
${ }^{15}$ Germany, Andorra, Belgium, Spain, France, Luxembourg, the Netherlands, the United Kingdom. Switzerland, South Africa, Namibia, Swaziland, Zimbabwe, Canada, the United States of America, Venezuela, Australia.

${ }^{16}$ In the 2019 national access competition, of the 3,500 available vacancies for emigrant descendants, 416 were filled, mainly with students from France, Brazil, Angola, Venezuela, Luxembourg, Switzerland, Macau, Mozambique and the United States of America (data retrieved from: https:// www.publico.pt/2019/09/29/sociedade/noticia/lusodescendentes-ensino-superiorportugues-aumentaram-150-quatro-anos-1888260)
} 
language and culture, to social, political, cultural and economic inclusion in the host countries, to training and formation of associative leaders and the promotion of gender and citizenship equality in communities abroad (Portal das Comunidades Portuguesas 2017b). There is an annual call for proposals for actions to be developed by the associations abroad or by associations in Portugal that develop actions abroad. The support consists in a non-refundable financing of the activities proposed and are granted through the financing of actions and projects, up to a maximum of $80 \%$ or $50 \%$ of the value deemed eligible for the budget presented, depending on whether they are entities based abroad or in Portugal. ${ }^{17}$ Associations wishing to apply have to be accredited at the General-Directorate for Consular Affairs and Portuguese Communities that runs this policy.

\subsection{Diaspora Policies and Social Protection in Portugal}

In Portugal, the main risks and needs covered by the national social security system are unemployment, health care, retirement pensions (old age), family, minimum social income - universal basic income, and, in supplementary form, access to education or housing. These benefits are subject to the national legislation on welfare and are directed towards individuals (national or foreigners) living in Portugal. Portuguese citizens abroad can usually only benefit from these services and policies after returning to Portugal. The exception are pensioners and the large population of Portuguese posted workers conducting short-term missions in another European Union (EU) Member State. Posting of workers - that is often confused with migration-is a particular source of concern to the Portuguese authorities. They are however, technically speaking, not citizens residing abroad, as they continue to pay their compulsory social security contributions in Portugal and thus continue to be covered by the Portuguese social security system (Law n. ${ }^{\circ} 64 / 93,5$ of March).

Because social protection is traditionally linked to residence, the engagement of the Ministry of Foreign Affairs, through its consular network, in the area of social protection can be considered as weak. The activities of the consular network are more commonly related with registration acts, issuing of travel documents, and electoral census acts. Yet, consulates are also involved in the monitoring of cases of labour exploitation, Portuguese detainees abroad, deportations or expulsions of Portuguese citizens, as well as the provision of social support to those deprived residing abroad (Sousa 2017). In a very reduced number of Portuguese embassies abroad, there is the position of the social attaché to deal with those issues but, normally, this will be part of a junior diplomat's mission within the embassy personnel. Overall, there is no national strategy directed towards the specific social protection needs of nationals abroad, as Portuguese authorities tend to limit their responses to specific situations, mainly in the case of deprivation and when repatriation is needed.

${ }^{17}$ Law n ${ }^{\circ} 124 / 2017,27$ June. 
Similarly, there is no real strategy to inform nationals abroad about social protection rights and obligations. The information available is mainly aimed at citizens who intend to emigrate and aims at raising awareness on precautions to take before going abroad or those aiming to return and the administrative and fiscal issues they need to prevent.

Information on repatriation policies and procedures (conditions, obligations) are scarce. In accordance with the Decree-Law 162/2006 (8 August 2006), repatriation of Portuguese citizens can occur when citizens lack the necessary means to support return costs; due to medical reasons that advise, in situations of danger of life, the immediate return, due to impossibility of local treatment; and in cases of expulsion. Each situation is evaluated by the consular section. Except in cases of expulsion, repatriation only takes place by the express will of the concerned citizen or her/his representative. Repatriated Portuguese who have the means to reimburse the state the amounts spent in the repatriation process shall, in a written declaration, take the reimbursement commitment. Numbers of repatriation have been declining in the last 2 years, from 108 in 2016 to 75 in 2017.

In recent years, the main reasons for repatriation has been accidents, weather conditions (Irma hurricane in 2017, for example), irregular presence in host country (e.g., in Canada, or the USA), political and economic instability in host countries (e.g., Venezuela). Regarding irregular presence, the number of repatriations from Canada and the USA are not very high, six from Canada (between 2016 and 2017), and 44 from the USA for the same period.

There are two social protection measures explicitly developed for Portuguese citizens abroad and managed by Portuguese consulates: the 'Social support for the deprived elderly of the Portuguese communities' (ASIC-CP) aimed at deprived Portuguese seniors of at least 65 years old, and the 'Social support for the deprived migrants of the Portuguese communities' (ASEC-CP) (see below).

Beyond social security cooperation in the EU framework, one area where Portugal has been very active in terms of access to social protection of individuals in situation of mobility is the signature of bilateral social security agreements. These agreements guarantee that returning emigrants are covered by the national social security system in case of unemployment, disease, old age, family, and, in a supplementary form, have access to education or housing of its members.

Currently, Portugal has 23 bilateral agreements on social security matters with different countries or regions. ${ }^{18}$ Most of these agreements are not related to the emigration of Portuguese citizens, but rather to the presence of immigrants from the signatory countries in Portugal. This orientation toward immigrants is expressed in the Social Security Law that explicitly state in its article 25 that "the State promotes the establishment of coordination instruments on social security with the aim of

\footnotetext{
${ }^{18}$ Currently bilateral agreements with the following countries are in place: Andorra, Angola, Argentina, Australia, Cabo Verde, Canada, Chile, Philippines, the UK, Guinea-Bissau, India, Morocco, Mozambique, Moldova, Romania, São Tomé and Príncipe, Tunisia, Ukraine, Uruguay, Venezuela. Besides these, Portugal signed European wide and Ibero-American wide multilateral agreements.
} 
ensuring equal treatment for the beneficiaries concerned who are engaged in professional activity or residing in their territory relatively to rights and obligations (Law n. ${ }^{\circ}$ 4/2007, 16 January).

Due to reciprocity principle, the agreements also apply to Portuguese emigrants living in these countries. Among the countries with which agreements were signed, it is possible to note the presence of countries with a sizeable Portuguese community (Andorra, Angola, Canada, and the UK) and countries were the presence of Portuguese citizens is rather small (Moldova or Ukraine).

The social policies field covered by the different agreements are displayed in Table 23.1. Social policy fields of old age, health care and family policy are the main subjects of such agreements. The matters included in these conventions are governed by "the basic principles that guide the international coordination of Social security legislation (...), in a framework of global reciprocity and of the specific bilateral relationship between them [the States]" (Silva, 2005, cit in Peixoto et al. 2011: 72).

In 2017, Portugal signed the Ibero-American Multilateral Agreement on Social Security and is currently one of the 11 countries where the agreement is in force. This agreement "deals with contributory financial benefits for disability, old-age, survivors, and those resulting from accidents at work and occupational illnesses" (Riaño 2018), and foresees the possibility to extend it to other areas.

If the emigrant resides in a country that has not signed any international social security agreement with Portugal and has never contributed for the Portuguese social security, there are several situations in which he/she will continue to benefit from the Portuguese regime or the scheme for which he/she has contributed in the country where he/she worked. If the emigrant carries out a professional activity in a foreign country and is not covered by any international social security system to which Portugal is linked, he/she may require Voluntary Social Insurance. This is an optional contributory scheme aiming to guarantee the right to social security for persons over 18 years of age and who are eligible for work that are not compulsorily included in any social protection schemes. Social protection covered by Voluntary Social Insurance varies depending on the activity exercised, including, in most cases, disability, old age and death grants (Alto Comissariado para as Migrações 2018).

Table 23.1 Social policy fields covered by bilateral social security agreements

\begin{tabular}{l|l}
\hline Social policy field & $N$ \\
\hline Invalidity benefits & 22 \\
\hline Old age benefit & 23 \\
\hline Death grant & 17 \\
\hline Survivor's benefits & 20 \\
\hline Work injuries & 16 \\
\hline Maternity insurance & 13
\end{tabular}

Source: Bilateral agreements with several countries (Segurança Social $2018 \mathrm{a}, \mathrm{b})$ 
In the next sub-sections, we look more precisely at five social protection dimensions in order to identify the engagement of Portuguese authorities with their citizens abroad.

\subsubsection{Unemployment}

As provided by the EU legislation, an unemployed individual who receives unemployment benefits can leave the country to search for work in another EU Member State and continue to temporarily receive the unemployment benefit. Before leaving, he/she has to inform the employment center and request from the social security services the U2 portable document that will allow him/her to obtain the authorisation to transfer unemployment benefits to another country (Instituto da Segurança Social 2019). Beyond this, there is no policy to assist Portuguese citizens abroad in accessing unemployment benefits (either in home or host country). To be eligible for the unemployment benefit, residence in Portugal is necessary.

There is also no separate unemployment or training scheme for nationals abroad. If emigrants are not covered by a social security scheme abroad, they can pay (while abroad) the Voluntarily Social Security, but this does not allow them generally to access unemployment benefits. The contribution to the Voluntarily Social Security only allows Portuguese citizens abroad to access benefits in cases of disability, old age and death grants. Also, unlike other states, the Portuguese Government does not provide any training for citizens wanting to emigrate. General information is available for those that want to work or live abroad (Portal das Comunidades Portuguesas 2018f).

Looking at consular services, their main mission in the area of employment concerns the monitoring of labour exploitation cases and situations of contract breach. According to data from the yearly emigration report, between 2012 and 2017, 168 cases of labour exploitation/contract breach where registered. Overdue payments, low wages, lack of company support, and breach of contractual obligations are the main situations reported by exploited workers. Situations of employment exploitation are forwarded to the competent consular posts or sections to analyse and provide the necessary support, and to the IEFP (Portuguese Employment Institute) or ACT (Authority for Work Conditions) to carry out the proper inspection and control and to contact their foreign counterparts.

Overall, since the mass migration of Portuguese citizens in the nineteenth century, guaranteeing safe working conditions has been one concern of the state. The size of the outflows and the occupational sectors in which a substantial part of emigrants work (e.g. construction, agriculture, hotel industry) make the pursuing of this state's concern difficult. It has been based mainly on emigrants' complaints and on information campaigns directed towards those who wish to emigrate. 


\subsubsection{Health Care}

Beyond the EU framework, there is no policy to assist Portuguese citizens abroad in accessing health care (either in home or host country). The National Health Service does not provide information for citizens living abroad, it can be used by residents in Portugal (nationals or foreigners). Consulates' functions regarding health care only involves the facilitation of contact with host country hospital units in case of accident or illness (Portal das Comunidades Portuguesas 2017a) and repatriation of citizens when host country's health services are not available.

In cases of accidents, consulates shall provide assistance equivalent to the support received in Portugal, seeking to ensure the necessary medical assistance and taking all other measures appropriate to the situation. ${ }^{19}$ Citizens who received help from the consulates and have the means to reimburse the state have to sign a written declaration stating their commitment of reimbursement. The law does not give any further indications on the conditions in which this assistance is made and on the situations that allow a citizen to seek help from the consulates.

The remaining articles that the law devote to the provision of extraterritorial assistance of Portuguese citizens regard accounting matters like that the reimbursement shall be made to the exchange rate prevailing at the time of the assistance, or the obligation of the holders of the consular post to refer monthly to the Ministry of Foreign Affairs the expenses incurred with the aid provided.

\subsubsection{Pensions}

Bilateral social security conventions frequently concern pension agreements (see Table 23.1) and often postulate measures for the cumulation of contributions periods in the signing states. In addition, multilateral agreements, like the IberoAmerican agreement mentioned before, foresee similar provisions for pensions.

Portuguese pensions are exportable, which entails that Portuguese citizens living abroad can claim Portuguese state pension if they have worked and paid enough contributions for the Portuguese social security. They should have paid for social security or other social protection system for 15 years (continuous or not). If they are beneficiaries of the Voluntary Social Insurance, a period of 144 months of contributions is necessary. If they do not have the necessary discounts (warranty period), they may be entitled to the social old-age pension.

For emigrants that receive their pensions abroad (as for the general population), life certificate is only needed when requested by the Portuguese social security system. Portuguese consulates abroad can issue such certificates.

Next to these limited interventions in the area of pension, it is important to note the existence of a specific scheme for old-age Portuguese citizens abroad in

${ }^{19}$ Law n ${ }^{\circ} 71 / 2009$, from March 31. 
situation of deprivation that has been set up in 2000: the 'Social support for the deprived elderly of the Portuguese communities' (ASIC-CP). This measure is aimed at Portuguese nationals of at least 65 years old, with legal residency abroad, in a situation of proven economic necessity, and without family members obliged to provide food or if these are not able to provide them with food. ${ }^{20}$ The primary objective of this measure is to provide minimum subsistence condition, including accommodation, food, healthcare and hygiene. It materialises as a personal allowance, paid monthly through cheques to residents in a foreign country, except for residents in Brazil who receive the money quarterly by bank transfer. The total budget for this form of support decreased from 1,7 million euro in 2015 to 1,5 million in 2016, accompanying the decline in the number of beneficiaries (from 863 to 774). The value that is given to each recipient varies depending on the value of the host country's social pension (or equivalent) and cannot be more than the minimum pension of the contributory regime in force in Portugal at the beginning of the 2nd semester of each year ${ }^{21}$ (in 2018, between $269 €$ and 389€). Between 2013 and 2017, the State department responsible for managing the requests (General Direction of Consular Affairs and Portuguese Communities) received 108 applications. At the end of 2017, the state supported 774 beneficiaries in 14 countries (Gabinete do Secretário de Estado das Comunidades Portuguesas 2014, 2015, 2016, 2017, 2018) (Table 23.2).

\subsubsection{Family-Related Benefits}

Beyond what is provided by the EU framework, Portuguese citizens living abroad cannot access child benefits from Portugal. Portugal's intervention in this area is limited mostly to the delivery of birth certificates at the consulate in case the

Table 23.2 Country of residence of the beneficiaries of the social support for the deprived elderly of the Portuguese communities (main countries), 2013-2017

\begin{tabular}{l|l|l|l|l|l}
\hline \multirow{2}{*}{ Country } & \multicolumn{5}{l}{ Number of beneficiaries } \\
\cline { 2 - 6 } & 2013 & 2014 & 2015 & 2016 & 2017 \\
\hline Brazil & 637 & 612 & 604 & 583 & 545 \\
\hline Venezuela & 85 & 84 & 82 & 76 & 71 \\
\hline Mozambique & 71 & 67 & 56 & 55 & 50 \\
\hline South Africa & 64 & 64 & 57 & 58 & 54 \\
\hline Zimbabwe & 28 & 26 & 23 & 22 & 21 \\
\hline Angola & 21 & 21 & 20 & 17 & 17 \\
\hline Other & 41 & 36 & 21 & 18 & 16 \\
\hline Total & 947 & 910 & 863 & 829 & 774 \\
\hline
\end{tabular}

Source: Gabinete do Secretário de Estado das Comunidades Portuguesas (2014, 2015, 2016, 2017, 2018)

\footnotetext{
${ }^{20}$ Despacho conjunto $\mathrm{n} .{ }^{\circ} 17 / 2000$, from 7 th January.

${ }^{21}$ Decreto Regulamentar $n .^{\circ} 33 / 2002$, from 23rd April.
} 
children were born abroad and were registered at a national consular post. Also, home country birth certificates can be requested at a consular post (Portal das Comunidades Portuguesas 2018d).

The registration at the Portuguese consulate of a foreign-born child of a Portuguese parent make them Portuguese citizens. When this registration is not made, voluntary acquisition of Portuguese citizenship by descendants born abroad is also possible by declaring that they want to be Portuguese. In this case, foreignborn descendants of a Portuguese citizen need a birth certificate to access Portuguese citizenship. This form of acquiring the Portuguese citizenship is also possible for grandchildren of a Portuguese citizen. The recognition as Portuguese citizens of foreign-born descendants allow them to access the general constitutional rights and measures of 'positive discrimination' foreseen in the Portuguese Constitution and in specific laws. One of these measures refers to access to higher education, being legally consecrated a special contingent (equivalent to $7 \%$ of the vacancies set for the first phase of application, see above), intended to ensure admission to Portuguese emigrant candidates and relatives who with them reside. ${ }^{22}$

\subsubsection{Economic Hardship}

There is no policy to assist Portuguese citizens abroad in accessing minimum resources either in cash or in-kind (either in home or host country). In case of economic hardship, consulates can promote the repatriation to Portugal in exceptional circumstances and proven economic failure. Repatriation is only possible when other means to overcome the economic hardship of the emigrant are not possible and after signing an agreement for reimbursement of the amount spent. When citizens have no financial means to pay their return trip, the consular missions will make the necessary arrangements.

Next to this apparently restrictive approach to respond to economic hardship of Portuguese citizens residing abroad, a specific scheme was created in 2002 to respond to this situation: the 'Social support for the deprived migrants of the Portuguese communities' (ASEC-CP) ${ }^{23}$ The recipients of this instrument are emigrants and their families who are in a situation of proven lack of means of survival or that show great vulnerability not surmountable by the social protection and health mechanisms that exist in the countries of residence.

The institutionalization of measures aimed to help Portuguese citizens deprived of means of subsistence means that the state recognizes that migration is not always a success story. It arises from the frequent reports about the existence of Portuguese in a situation of economic deprivation and the pressure exerted by associations of emigrants, members of the Council of Portuguese Communities, and members of

\footnotetext{
${ }^{22}$ Ordinance $n .^{\circ} 211 / 2018$, from 17 th July.

${ }^{23}$ Regulatory Decree n. ${ }^{\circ}$ 33/2002, from 23rd April.
} 
political parties with responsibilities in the area of emigration. As outlined in the preamble of the Decree-Law that creates this support scheme, "among the first- and second-generation Portuguese in the host countries, not all of them live in a favourable economic situation. There are situations, especially in Latin America, in which Portuguese - who have been looking for the sustenance they have not found in their country - are experiencing dramatic situations today, both socially and financially, that their home country has an obligation to help to resolve or, at the least, assist." (Decree-Law 33/2002, 23rd April).

This scheme particularly targets victims of crimes against physical integrity, of natural and public disasters, of extraordinary events, of serious illness requiring urgent treatment, surgical intervention or other; disabled or victims of a disabling accident in a situation of dependence that needs technical help to improve their living conditions. It is a punctual and extraordinary individual or family allowance whose amount is variable, taking into account the socio-economic situation of the person, and of its household. Between 2013 and 2016, 39 requests were made for this allowance, mainly from Brazil and South Africa (Gabinete do Secretário de Estado das Comunidades Portuguesas 2014, 2015, 2016, 2017).

\subsection{Conclusions}

Albeit being a country of emigration for the most part of its history, Portugal has not developed sound policies of social protection directly intended for its citizens living abroad. Existent policies are mainly directed towards the extra-territorial extension of rights (voting rights), or to the maintenance of a cultural link between citizens abroad and the country of origin (Portuguese language and culture for citizens abroad). The attention given to measures intended to deepen the connection of emigrants to the Portuguese state through, for example, the creation of conditions for the maintenance of Portuguese language and culture, is justified by the historical relevance of emigration in Portugal and by the attempt to construct an image of the state that is greater than the limits of its territory. Regarding the state apparatus created by the Portuguese Government to support emigrants (e.g. through its consular representations), it could be argued that these policies, state services abroad, and symbolic politics are also intended to "ensure that migrants remain enduring long distance membership" (Levitt and de la Dehesa 2003).

The existing measures of social protection either derive from the ones applicable to the general Portuguese population and thus depend on the return of citizens abroad or address extreme causes of deprivation that result from the deterioration of living conditions, or the development of unstable economic and political conditions. The late development of the welfare state in the country and its fragile nature when compared with other European welfare systems help to explain the incomplete extension of social protection to citizens abroad. Its expansion beyond the Portuguese territory gained a greater prominence since the 1980s. As shown in the previous sections, this late institutionalization of the welfare state and its "territorial index" 
(Bommes 2012) accounted for its slow and incomplete extension to Portuguese citizens living in another country. The involvement of the representations of the Portuguese state abroad in the area of social protection is limited to bureaucratic practices (e.g. issue of birth certificates), and to extreme situations. The social protection of citizens abroad is thus visible in the provision of social support to the deprived, in the monitoring of cases of labour exploitation, in assistance to Portuguese detainees abroad, and in situations of deportation, expulsion or equivalent of Portuguese citizens. More traditional areas of the welfare such as unemployment, health care, pensions, etc. did not apply to emigrants and their descendants while abroad. Welfare and social protection in Portugal thus continue to be linked to a jus domicilis (residence in a territory) principle, albeit allowing emigrants to access benefits if they made contributions to the Portuguese welfare system during their working life. The protection of emigrants in extreme situations (e.g. exploitation, incarceration, or expulsion) and the guarantee of their social benefits inscribed in the national Constitution are pursued at different scales. The first has an external dimension involving the intervention of the state institutions to assure their fulfilment. The second has an international dimension and are secured through the EU framework and a set of conventions on social security signed between Portugal and several host countries. These conventions expand to Portuguese citizens living in a foreign state the protection that these states offer to their nationals and recognize their contributions in these countries to calculate access to social benefits (SantanaPereira and Horta 2017). While the first has a long tradition in the Portuguese emigration policy, being a constant theme in the debates on emigration (Pereira 2002; Marques and Góis 2016), the second had a slow development since the late 1950, gaining more prominence after the authoritarian regime in 1974 with the establishment of several social programs and an increasing need of international cooperation. The bilateral and multilateral conventions on social security that Portugal signed with other countries seek to enssure the portability of the social rights that emigrants acquired while abroad and guarantee that Portuguese citizens are treated equally in the host countries. These general objectives of the social protection of citizens living abroad are generally consensual among political parties. Debates and disputes only emerge on the application of this protection when extreme events arise (political and economic crisis in host countries), and when a situation of deprivation or exploitation becomes publicly known. State policies to reach citizens abroad testifies the limits of the Portuguese welfare state in action. The image of an internally weak social protection system is surpassed by the frequent ad hoc measures adopted to support vulnerable Portuguese emigrants. Through these actions, the state projects an image of an always present state that extents the obligation to protect its citizens beyond the limits of its territorially confined borders.

Acknowledgements This chapter is part of the project "Migration and Transnational Social Protection in (Post)Crisis Europe (MiTSoPro)" that has received funding from the European Research Council (ERC) under the European Union's Horizon 2020 research and innovation programme (Grant agreement No. 680014). In addition to this chapter, readers can find a series of 
indicators comparing national social protection and diaspora policies across 40 countries on the following website: http://labos.ulg.ac.be/socialprotection/.

This chapter was prepared with support from the research project "Experiences and expectations of return of new Portuguese emigrants: reintegration and mobilities", financed by the Portuguese national funding agency for science, research and technology (FCT), under Grant PTDC/SOC-SOC/28730/2017.

\section{References}

Aguiar, M. M. (2009). O Conselho das Comunidades e a Representação dos Emigrantes. Revista Migrações - Número Temático Migrações entre Portugal e América Latina, (5), 257-262.

Alto Comissariado para as Migrações (2018). Segurança Social. https://www.acm.gov.pt/-/seguranca-soci-1. Accessed 15 Dec 2018.

Baganha, M., \& Marques, J. C. (2001). População. In N. Valério (Ed.), Estatísticas Históricas Portuguesas (Vol. I, pp. 33-126). Lisboa: INE.

Bommes, M. (2012). Welfare systems and migrant minorities. The cultural dimension of social policies and its discriminatory potential. In C. Boswell \& G. D'Amato (Eds.), Immigration and Social Systems. Collected Essays of Michael Bommes (pp. 83-106). Amsterdam: Amsterdam University Press.

Comissão Nacional de Eleições. (2015). Mapa Oficial n..$^{\circ}$ 2-B/2015. http://www.cne.pt/sites/ default/files/dl/ar2015_mapa_oficial_resultados.pdf. Accessed 1 Feb 2019.

Costa, P. M. (2000). A participação dos portugueses não residentes e dos estrangeiros residentes nas eleições portuguesas. Documentação e Direito Comparado (81/82), 180-216.

Gabinete do Secretário de Estado das Comunidades Portuguesas. (2014). Relatório da Emigração 2013. Lisboa: Gabinete do Secretário de Estado das Comunidades Portuguesas.

Gabinete do Secretário de Estado das Comunidades Portuguesas. (2015). Relatório da Emigração 2014. Lisboa: Gabinete do Secretário de Estado das Comunidades Portuguesas.

Gabinete do Secretário de Estado das Comunidades Portuguesas. (2016). Relatório da Emigração 2015. Lisboa: Gabinete do Secretário de Estado das Comunidades Portuguesas.

Gabinete do Secretário de Estado das Comunidades Portuguesas. (2017). Relatório da Emigração 2016. Lisboa: Gabinete do Secretário de Estado das Comunidades Portuguesas.

Gabinete do Secretário de Estado das Comunidades Portuguesas. (2018). Relatório da Emigração 2017. Lisboa: Gabinete do Secretário de Estado das Comunidades Portuguesas.

Gamlen, A. (2008). The emigration state and the modern geopolitical imagination. Political Geography, 27, 840-856.

Governo de Portugal (2015). Plano Estratégico para as Migrações 2015-2020. Lisboa: Gabinete do Secretário de Estado Adjunto do Ministro Adjunto e do Desenvolvimento Regional (http:// www.programaescolhas.pt/_cf/364724).

Governo dos Açores. (2018). Direção Regional das Comunidades. http://www.azores.gov.pt/ Portal/pt/entidades/srapre-drcomunidades/. Accessed 12 Jun 2018.

Instituto Camões. (2018). Who we are. https://www.instituto-camoes.pt/en/institutional/about-us/ who-we-are. Accessed 12 Nov 2018.

Instituto da Segurança Social. (2019). Guia Prático - Subsídio de Desemprego. http://www.segsocial.pt/documents/10152/24581/6001_subsidio_desemprego/1867b682-64f2-4b1a-8f39ca008602a16b. Accessed 1 Jan 2019.

Levitt, P., \& de la Dehesa, R. (2003). Transnational Migration and the Redefinition of the State: Variations and Explanations. Ethnic and Racial Studies, 26(4), 587-611.

Marques, J. C., \& Góis, P. (2013a). Dinâmicas do sistema migratório lusófono: um olhar a partir das migrações portuguesas. In L. Fonseca, P. Góis, J. C. Marques, \& J. Peixoto (Eds.), Migrações 
na Europa e em Portugal. Ensaios de homenagem a Maria Ioannis Baganha (pp. 185-203). Coimbra: Almedina.

Marques, J. C., \& Góis, P. (2013b). Portuguese emigrants and the State: An ambivalent relationship. In M. Collyer (Ed.), Emigration Nations: the ideologies and policies of emigrant engagement (pp. 252-276). Houndmills: Palgrave Macmillan.

Marques, J. C., \& Góis, P. (2014). A emigração portuguesa contemporânea e o Estado: uma Nação dispersa, um Estado longínquo. População e Sociedade, 22, 55-71.

Marques, J. C., \& Góis, P. (2016). Structural emigration: the revival of Portuguese outflows. In J.-M. Lafleur \& M. Stanek (Eds.), Old Routes, New Migrants: Lessons from the South-North Migration of EU Citizens in Times of Crisis (pp. 65-82). Heidelberg: Springer.

Peixoto, J., Marçalo, C., \& Tolentino, N. (2011). Imigrantes e Segurança Social em Portugal. Lisboa: ACIDI IP.

Pereira, M. H. (2002). A politica portuguesa de emigração: 1850-1930. São Paulo: Editora da Universidade do Sagrado Coração/Instituto Camões.

Pereira, M. H. (2005). The origins of the welfare state in Portugal: The new frontiers between public and private. Portuguese Journal of Social Sciences, (4), 3-26.

Portal das Comunidades Portuguesas. (2017a). Conselhos aos Viajantes Portugueses. https:// www.portaldascomunidades.mne.pt/images/Super0Users/Brochura_CONSELHOS_AOS_ VIAJANTES_26_FEV.pdf. Accessed 15 Dec 2018.

Portal das Comunidades Portuguesas. (2017b). FAQs - Atribuição de Apoios pela DGACCP. https://www.portaldascomunidades.mne.pt/pt/apoios/area-cultural-e-movimentoassociativo-old/644-faqs-atribuicao-de-apoios-pela-dgaccp\#a-quem-se-destinam-os-apoiosfinanceiros. Accessed 21 Nov 2018.

Portal das Comunidades Portuguesas. (2018a). Listagem de Conselheiros Eleitos. https://www. portaldascomunidades.mne.pt/images/GADG/Listagem_de_Conselheiros___Portal_das_ Comunidades_6.pdf. Accessed 28 Apr 2018.

Portal das Comunidades Portuguesas. (2018b). Permanências Consulares. https://www.portaldascomunidades.mne.pt/pt/permanencias-consulares. Accessed 20 May 2018.

Portal das Comunidades Portuguesas. (2018c). Rede Consular. https://www.portaldascomunidades.mne.pt/pt/rede-consular. Accessed 22 May 2018.

Portal das Comunidades Portuguesas. (2018d). Registo Civil - Nascimento. https://www.portaldascomunidades.mne.pt/pt/servicos-consulares/registo-civil/489-nascimento. Accessed 22 Apr 2018.

Portal das Comunidades Portuguesas. (2018e). Regulamento Interno da Comissão Temática para as Questões Sociais e Económicas e dos Fluxos Migratórios. https://www.portaldascomunidades. mne.pt/images/GADG/REGULAMENTO_INTERNO_CSEFM.pdf. Accessed 4 May 2018.

Portal das Comunidades Portuguesas (2018f). Trabalhar e Viver no Estrangeiro. https://www. portaldascomunidades.mne.pt/pt/trabalhar-e-viver-no-estrangeiro. Accessed 10 Nov 2018.

Portal das Comunidades Portuguesas. (2019). Atividade Consular no Mundo, 2017. https://www. portaldascomunidades.mne.pt/images/GADG/Atividade_Consular_no_mundo_2017.pdf. Accessed 2 Feb 2019.

Riaño, G. (2018). Ibero-American Multilateral Agreement on Social Security. EU-LAC Newsletter(02/2018), 10-11.

Rodrigues, F., Freire, A., Carvalhais, I. E., Amador, I., Queiroga, V., \& Morgado, J. (2013). Participação Eleitoral dos Imigrantes e Emigrantes de Portugal. Lisboa: OIM.

Santana-Pereira, J., \& Horta, A. P. B. (2017). A Global Nation? The Evolution of Emigration and Diaspora Policies in Portugal (1960-2016). In A. Weinar (Ed.), Emigration and Diaspora Policies in the Age of Mobility (pp. 121-137). New York: Springer.

Secretaria Geral do Ministério da Administração Interna. (2020). Eleições Resultados dos Escrutínios Provisórios. Retrieved from: https://www.eleicoes.mai.gov.pt/legislativas2019/.

Segurança Social. (2018a). Legislação. http://www.seg-social.pt/legislacao?kw=Conven\%C3\%A7 \%C3\%A3o. Accessed 15 Dec 2018. 
Segurança Social. (2018b). Mobilidade internacional. http://www.seg-social.pt/mobilidade-internacional. Accessed 15 Dec 2018.

Sousa, P. P. (2017). A diáspora portuguesa como prioridade da política externa de Portugal: entre o discurso e a prática. História. Revista da FLUP, IV Série, 7, 57-78.

Open Access This chapter is licensed under the terms of the Creative Commons Attribution 4.0 International License (http://creativecommons.org/licenses/by/4.0/), which permits use, sharing, adaptation, distribution and reproduction in any medium or format, as long as you give appropriate credit to the original author(s) and the source, provide a link to the Creative Commons license and indicate if changes were made.

The images or other third party material in this chapter are included in the chapter's Creative Commons license, unless indicated otherwise in a credit line to the material. If material is not included in the chapter's Creative Commons license and your intended use is not permitted by statutory regulation or exceeds the permitted use, you will need to obtain permission directly from the copyright holder.

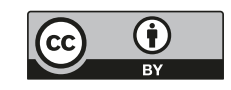

